\section{The Effects of Doctoral Teaching Development on Early-Career STEM Scholars' College Teaching Self-efficacy}

Mark R. Connolly, * You-Geon Lee, and Julia N. Savoy

Wisconsin Center for Education Research, University of Wisconsin-Madison, Madison, WI 53706

\begin{abstract}
To help prepare future faculty in science, technology, engineering, and mathematics (STEM) to teach undergraduates, more research universities are offering teaching development (TD) programs to doctoral students who aspire to academic careers. Using social cognitive career theory, we examine the effects of TD programs on early-career STEM scholars' sense of self-efficacy as postsecondary teachers. In 2011, a survey questionnaire was administered to 2156 people who in 2009 were doctoral students in STEM departments at three U.S. research universities; 1445 responded (67\%). Regression analysis revealed positive relationships between TD participation and participants' college teaching self-efficacy and positive interaction effects for women. These findings may be used to improve the quality and quantity of TD offerings and help them gain wider acceptance.
\end{abstract}

\section{INTRODUCTION}

Over the past decade, retaining and graduating more undergraduate students with training in STEM (science, technology, engineering, and mathematics) fields has become a national priority (cf. National Research Council [NRC], 2011; Office of Science and Technology Policy, 2013, 2016). In particular, policy makers and funders are paying closer attention to the quality of undergraduate STEM instruction, especially to which teaching practices are proven effective by research and practice and how faculty learn to adopt instructional practices that engage more students (Henderson et al., 2011; NRC, 2012; Kober, 2015). Not surprisingly, when the President's Council of Advisors on Science and Technology (2012) called for a million additional STEM graduates over the next decade, its top policy recommendation was "to train current and future faculty in evidence-based teaching practices" (p. iv). Similarly, when the Association of American Universities launched a 5-year project to reform undergraduate STEM education, four of its five policy goals focused on improving teaching in STEM courses (Association of American Universities, 2014). A sourcebook calling for systemic change in STEM higher education included "supporting faculty development" as one of seven overarching goals (Coalition for Reform of Undergraduate STEM Education, 2014, p. 5). Together, these initiatives suggest that preparing faculty more effectively as undergraduate educators could be an effective systemic approach to improving undergraduate STEM education at scale.

Although efforts to improve postsecondary instruction generally have focused on current faculty, more attention is being given to how future faculty ${ }^{1}$ are being prepared to assume academic roles and responsibilities (e.g., Wulff and Austin, 2004; Hopwood and Stocks, 2008; Austin, 2010; Schönwetter and Ellis, 2010; Hershock et al., 2011; Kalish et al., 2011; Palmer, 2011; Wurgler et al., 2013). Doctoral training in STEM fields has traditionally consisted of a doctoral student working closely with a faculty advisor to learn the research methods and content knowledge that are constitutive of the discipline (Walker et al., 2008; Anderson et al., 2011). This apprenticeship model
Kenneth Gibbs, Monitoring Editor Submitted March 13, 2017; Revised November 20 , 2017; Accepted November 30, 2017

CBE Life Sci Educ March 1, 2018 17:ar14 DOI:10.1187/cbe.17-02-0039

*Address correspondence to: Mark R. Connolly (mark.connolly@wisc.edu).

() 2018 M. R. Connolly et al. CBE-Life Sciences Education @ 2018 The American Society for Cell Biology. This article is distributed by The American Society for Cell Biology under license from the author(s). It is available to the public under an Attribution-Noncommercial-Share Alike 3.0 Unported Creative Commons License (http://creativecommons.org/licenses/ by-nc-sa/3.0).

"ASCB®" and "The American Society for Cell Biology $\circledR^{\prime \prime}$ are registered trademarks of The American Society for Cell Biology. 
tends to emphasize doctoral students' formation as researchers and scholars and, as such, does not focus as intentionally on preparing academic aspirants to handle the full range of roles and responsibilities of 21st-century academics, including teaching (Austin and McDaniels, 2006; Feldon et al., 2011). As a result, doctoral students often report feeling quite confident about their research skills but far less prepared for teaching and advising responsibilities (Golde and Dore, 2001). Because almost half (46\%) of STEM PhDs are involved in some kind of college teaching within 5 years of completing a doctorate (Connolly et al., 2016), professional development in teaching is needed for the many doctoral students who will teach, train, and mentor the next generation of STEM undergraduates.

\section{Future Faculty Programs for STEM Doctoral Students}

Over the past two decades, professional development programs for future faculty have emerged to help doctoral students understand faculty roles and responsibilities. These programs range in scope from modest departmental offerings to national, multi-institutional initiatives (DeNeef, 2002; Weisbuch, 2004; Austin et al., 2008; Denecke et al., 2017). Although future faculty programs may address topics such as fostering diversity in the sciences, ethical conduct of research, and academic job hunting, a major component of most programs is teaching development (TD) - that is, helping doctoral students gain the knowledge, skills, and values needed to effectively teach undergraduates. How TD is provided to doctoral students varies, but institutions typically provide programs through some combination of their academic units (departments and colleges), graduate school, and center for teaching and learning. TD offerings also vary in format and duration, ranging from low-engagement events such as brown-bag discussions and one-off workshops to more intensive semester-length pedagogy courses and certificate programs in college teaching (Connolly et al., 2010). In general, these programs seek three reformoriented outcomes: 1 ) to improve the quality of undergraduate education by enhancing participants' pedagogical skills; 2) to provide training that better reflects the full range of faculty responsibilities; and 3) to change the culture and practice of graduate preparation such that undergraduate education is taken more seriously (Gaff and Lambert, 1996; Austin and Wulff, 2004; Goldsmith et al., 2004).

Although future faculty programs that emphasize TD are growing (Huber, 2016; Patel, 2017; Pfund et al., 2012), we still know very little collectively about their effects, especially on their participants' preparation as college instructors (Austin, 2010; Beach et al., 2016). To those concerned with improving undergraduate STEM education on a national scale, findings from small-scale studies and program evaluations are of limited usefulness. Administrators (including TD program coordinators), funders, and future faculty and their graduate advisors lack credible evidence that these programs improve participants' career options, enhance their early-career performance as academics, or improve undergraduate learning at a large scale. Lack of such evidence may not only affect doctoral students' interest in these programs but also jeopardize the programs' sustainability. Thus, if developing better postsecondary instructors is to advance the national STEM agenda, then more and better information is needed about the effects of typical TD programs for STEM doctoral students.
To address this issue, we conducted a longitudinal study of the impact of TD during doctoral training on a panel of earlycareer scholars who in 2009 were late-stage doctoral students in STEM departments at three U.S. research universities. In this paper, we first explain why social cognitive career theory (SCCT) is useful for understanding the short- and long-term impact of future faculty programs. Second, we describe a 2011 survey of early-career scholars and our procedures for analyzing those data. Third, we present findings showing that participation in doctoral TD is a significant predictor of early-career scholars' beliefs about their efficacy as college teachers and that TD offerings requiring more time and engagement are strongly associated with those efficacy beliefs. Finally, we discuss our findings' implications for the professional development of STEM earlycareer scholars against a backdrop of national efforts to improve undergraduate STEM teaching and learning.

\section{Conceptual Framework for Understanding Doctoral TD}

Higher education researchers studying doctoral student experiences frequently employ socialization theory, which considers how "an individual interacts, integrates, and learns the values, skills, attitudes, norms, and knowledge to effectively take part in a group" (Johnson et al., 2017, p. 1). The theory's strengths lie more in being descriptive of processes than predictive of outcomes, however. A different way to look at TD programs and their role in the formation of future faculty is offered by SCCT (Lent et al., 1994, 2000). SCCT is a career development model based on Bandura's (1986, 1997, 2005) general social cognitive theory, which posits that people learn by watching what others do, and the beliefs that people hold about themselves are key to their personal agency. To explain how one's career goals, career expectations, and sense of personal efficacy collectively shape career choices, SCCT integrates four models: 1) how career interests are formed, 2) how key career-related choices are made, 3) what constitutes effective job performance, and 4) what constitutes satisfying work. SCCT also accounts for how personal characteristics, social contexts, and learning experiences influence career-related choices and outcomes.

A central construct of social cognitive theory (and thus SCCT) is self-efficacy, which is a person's confidence in his or her ability to carry out a particular task or course of action (Bandura, 1986; Lent and Brown, 2006). By itself, self-efficacy has been studied widely, especially in educational contexts (Pajares, 1996; Usher and Pajares, 2008; Klassen and Usher, 2010). As applied to K-12 teachers, a teacher's efficacy belief is "a judgment of his or her capabilities to bring about desired outcomes of student engagement and learning, even among those students who may be difficult or unmotivated" (Tschannen-Moran and Woolfolk Hoy, 2001, p. 783). Teachers with stronger teaching self-efficacy beliefs tend to be more enthusiastic, devote more time to planning and organization, show greater commitment, be more likely to experiment with new methods, and be more persistent under adverse circumstances (Woolfolk Hoy, 2004). In his review, Ross (2013) asserts, "The evidence is consistent: Few teacher characteristics have as much impact on instructional practice and student outcomes as teacher efficacy" (p. 266).

Although the bulk of research on teaching self-efficacy is based on K-12 teachers, some studies have applied Bandura's 
ideas about self-efficacy to postsecondary instructors (e.g., Prieto and Altmaier, 1994; Santiago and Einarson, 1998; Major and Dolly, 2003; DeChenne et al., 2012). Because one's selfefficacy tends to be most malleable as a skill is first being learned, teaching self-efficacy beliefs of current and future faculty (hereafter called "college teaching self-efficacy") are significantly shaped while working as teaching assistants or participating in TD programs (Woolfolk Hoy, 2004). Given the robust body of evidence for the influence of self-efficacy on task performance (e.g., Pajares, 1996; Sitzmann and Ely, 2011), we should learn more about the college teaching self-efficacy of current and aspiring postsecondary faculty, because these beliefs are highly likely to influence how they perform as undergraduate instructors.

Thus, the primary advantage of using SCCT as a theoretical framework for the present study is that it not only examines self-efficacy related to a specific performance domain-STEM college teaching-but also situates self-efficacy in a career development model. As such, SCCT is well suited to studying how the college teaching self-efficacy of aspiring academics may affect, and be affected by, their career interests, their involvement in professional development activities, and their eventual career choices. Viewing the formation of postsecondary teachers through this lens is a challenge, though, because of the complexity of the SCCT model and the importance of constructing valid measures for each part of the model being investigated. If applied systematically and judiciously, however, SCCT has the potential to better explain the short-term effects of TD on doctoral student participants and the long-term effects on early-career scholars. SCCT also helps us determine which variables to use as covariates in our analyses.

Because research shows that self-efficacy beliefs may vary by gender and race/ethnicity, SCCT can also be used to examine the extent to which gender and race/ethnicity interact with the effects of TD programs on college teaching self-efficacy. Lindley's (2006) review, for example, examined critical differences in the strength of certain predictor variables for women and U.S. ethnic minorities. In most STEM domains, the selfefficacy beliefs of these underrepresented groups were often, but not always, lower than those of their majority peers. More recently, a meta-analysis of 247 independent studies on gender differences in academic self-efficacy found a small difference favoring men (Huang, 2013). Lindley (2006) further noted that research on self-efficacy sometimes but not consistently shows differences between racial/ethnic groups.

\section{Research Questions}

Using SCCT, we hypothesized that TD offerings can influence the learning experiences that directly inform college teaching self-efficacy. We focused on the relationship between TD experiences and college teaching self-efficacy of late-stage doctoral students and recent doctorate recipients-a group we call "earlycareer scholars." The present study explored three research questions related to early-career scholars' college teaching self-efficacy: 1) Does participation in any kind of TD relate to college teaching self-efficacy beliefs? If so, how much engagement matters? 2) Does the type of TD activity in which doctoral students participate matter to college teaching self-efficacy? 3) Are the relationships between TD activities and self-efficacy beliefs the same across gender and race/ethnicity?

\section{METHODS}

In 2008, the National Science Foundation (NSF) funded a 5 -year longitudinal study of the effects of TD programs on future STEM scholars. The mixed-method study used repeated surveys and interviews: 1) to follow the progress of a panel of late-stage doctoral students toward and after completing their doctorate; and 2) to explore the short- and long-term effects of TD participation on their pedagogical preparation, career choices, and early-career success. As part of that larger NSFfunded project, the present study examined the effects of TD on the college teaching self-efficacy of study participants who were enrolled as doctoral students at the three participating institutions in 2008 and who responded to a survey in 2009.

\section{Participant Characteristics and Sampling}

Data were collected 2 years apart (year $1=2009$, year $3=$ 2011) using two survey questionnaires developed for this study. The sampling frame for the year 1 instrument consisted of 3060 late-stage doctoral students in STEM departments at Arizona State University, the University of Washington-Seattle, and the University of Wisconsin-Madison. To define STEM for this study, we used NSF's four broad disciplinary categories: life sciences (which includes agricultural and biological sciences and health-related fields); physical sciences (computer, physical, mathematical, and earth, atmospheric, and oceanic sciences); engineering; and psychology and social sciences. Contact information for enrolled doctoral students in STEM departments was obtained directly from the graduate schools of the three institutions following approval from their respective institutional review boards. The year 1 questionnaire examined STEM doctoral students' participation in TD during their doctoral education. After its items were piloted and refined, the questionnaire was administered in paper- and Web-based formats in Summer 2009 by the University of Wisconsin Survey Center. The response rate was $73 \%(n=2163)$.

The second instrument was designed to measure SCCT constructs and gather information about respondents' current employment (e.g., employment sector, job title, distribution of academic responsibilities). With the exception of using a Webonly format, the method of administering the survey in 2011 was the same as in 2009. Of the 2156 year 1 respondents who could be reached, 1445 responded $(67 \%){ }^{2}$ Of these year 3

\footnotetext{
${ }^{2}$ Although this response rate is fairly good given the longitudinal nature of this survey, if any attrition at year 3 is systemically related to respondents' characteristics, it may introduce attrition bias, which makes it hard to make valid inferences from these data. While we found that some characteristics (particularly race/ethnicity, doctorate-granting institution, TD, and teaching experience) were associated with the likelihood of response in the year 3 survey, it turned out that the disproportionality of the response for some groups was already explained by other covariates Using inverse probability weights and propensity scores (Fitzgerald et al., 1998; Cuddeback et al., 2004; Foster and Fang, 2004; Miller and Hollist, 2007; Baulch and Quisumbing, 2011), we found that attrition bias did not substantially alter our conclusions, and it affected only a few estimates close to the margin of significance $(p=0.05)$. Although we found that attrition from the 2011 survey (year 3 ) did not substantially change our results, our data may still suffer from nonresponse bias if those who did not respond to the 2009 survey (year 1 ) were systematically different from those who did. However, the percentages of year 1 respondents resemble the corresponding percentages in the population. On the basis of results from supplemental analysis to test attrition bias between year 1 and year 3 surveys, we believe that nonresponse bias would not substantially change our findings and interpretations. Detailed information on population and survey respondents will be provided upon request.
} 
respondents, 977 (68\%) had earned their doctorate, and 468 (32\%) were still enrolled in a $\mathrm{PhD}$ program. These late-stage doctoral students and doctorate recipients $(N=1445)$ constitute our analytic group of early-career scholars. Listwise deletion was applied to handle missing data. Variables are described in Appendix A in the Supplemental Material.

\section{Outcome Measure}

The outcome measure of interest was college teaching selfefficacy. Previous research has linked teachers' self-efficacy to teaching performance and preferred student outcomes (Ross, 1998; Tschannen-Moran and Woolfolk Hoy, 2001). Because self-efficacy beliefs are specific to a particular performance domain, measuring self-efficacy requires breaking a performance domain into meaningful and ostensibly independent dimensions (Bandura, 2006; Betz and Hackett, 2006; Lent and Brown, 2006). Drawing on work that attempts to identify the various components of college teaching (e.g., Lowman, 1995; Hativa, 2000; Chism, 2007; Theall et al., 2009) and a synthesis of research on college teaching in science and math (NRC, 2003), we subdivided the general domain of postsecondary teaching into six dimensions: 1) course planning, 2) teaching methods, 3) creating learning environments, 4) assessing student learning, 5) interacting with students, and 6) mastering subject knowledge. Each dimension was initially measured by five items using five-point Likert-type scales ranging from 1 (not at all confident) to 5 (extremely confident).

To address content validity, we asked 10 scholars and administrators with expertise in faculty development, doctoral education, and undergraduate STEM education to review our items, which we revised based on their feedback. The construct validity of college teaching self-efficacy was addressed by exploratory factor analysis (EFA) and confirmatory factor analysis (CFA). As the names suggest, researchers first use EFA to explore ways of organizing observed variables into simpler groupings, and then use CFA to confirm or reject a hypothesis that those observed variables and their underlying constructs are truly related (Suhr, 2006). To conduct these analyses, we randomly divided the study's sample, first using EFA on one-half $(n=695)$ to identify the factor structure of college teaching self-efficacy, then using CFA on the other half $(n=696)$ to test this factor structure. ${ }^{3}$ EFA identified six factors, from which seven items were removed because they either did not load onto their corresponding factors (i.e., factor loadings $<0.5$ ) or loaded to a substantial degree (i.e., > 0.32) on more than one factor. The Cronbach's alpha coefficient of all six factors ranged from 0.88 to 0.91 , which indicated that internal consistency reliability was high. Using the six-factor model resulting from EFA, we conducted CFA on the second subsample and found that the model fit the data within acceptable limits. ${ }^{4}$ Therefore, EFA and CFA confirmed a six-dimensional structure of college teaching self-efficacy with a total of 23 items. ${ }^{5}$

\footnotetext{
${ }^{3}$ In EFA using the first subsample, the maximum-likelihood factor analysis with an oblique rotation was used to allow for correlations between all extracted factors. ${ }^{4}$ Root mean square error of approximation (RMSEA) $=0.058,90 \%$ confidence interval $\left(\mathrm{CI}_{90}\right)=0.053-0.063$; comparative fit index $(\mathrm{CFI})=0.958$; Tucker-Lewis index (TLI) =0.950; standardized root mean square residual $($ SRMR $)=0.035$.

${ }^{5}$ The distributions of each factor with means and standard deviations are presented in Supplemental Figure 1.
}

In our analyses, we treated each of the six dimensions of college teaching self-efficacy as an outcome. Each dimension had three, four, or five items, measured as five-point Likert-type scales. The average item scores for each dimension were used as dependent variables in the analysis. Each average item score was standardized (mean $=0 ; \mathrm{SD}=1$ ).

\section{Independent Variables of Interest}

Our primary objective was to estimate the effect of TD on college self-efficacy of early-career scholars in STEM fields. We expected that participation in TD would be positively associated with college teaching self-efficacy scores, and that such a relationship, if any, might differ according to participants' degree of engagement and type of program. To examine these hypotheses, we constructed three independent variables of interest. The first was overall participation in TD, measured dichotomously as "yes" or "no." The second was degree of engagement in TD activities, a continuous variable measuring cumulative hours spent participating in various TD activities during respondents' doctoral programs (range: 0-400 hours; mean $=39.4$ hours; SD $=50.1$ hours).$^{6}$ The third was type of participation in TD activities, measured as nonintensive, intensive, and formal courses. Nonintensive participation involves TD offerings that typically are less interactive for participants, such as one-off talks, presentations, and other activities lasting less than a day (Lee, 2010). Intensive participation involves TD offerings that typically are more interactive, such as trainings, workshops, and conferences. Formal courses are a distinctive type of TD participation, because courses typically are offered for academic credit, last an entire academic term, often are taught by a faculty member, and entail long-term interaction of instructor(s) and students. For our analysis, we defined both intensive participation and formal courses as including nonintensive participation, because people who participated in the first two types almost always participated in the third.

\section{Covariates}

In estimating the effect of the TD program, we controlled for not only respondents' demographic and academic backgrounds but also their teaching experience and initial career interests, which may affect respondents' college teaching self-efficacy, TD participation, TD engagement, and TD type. ${ }^{7}$ Covariates included 1) gender, 2) race/ethnicity, 3) citizenship, 4) year that doctoral study began, 5) amount of teaching experience, 6) primary career goal, 7) level of interest in teaching when starting their doctoral program, 8) principal field of study,

\footnotetext{
${ }^{6}$ The bivariate relationship between self-efficacy and cumulative hours of TD engagement appeared quadratic rather than linear. However, after accounting for relevant covariates, their multivariate relationships significantly favored the linear instead of quadratic function (likelihood ratio test results are available upon request). Thus, we assumed a linear relationship between each self-efficacy factor and cumulative hours of TD engagement in our final models.

${ }^{7}$ We recognize that self-confident doctoral students are more likely to participate or be engaged in TD activities, which could lead a self-selection bias for our estimates on the relationship between respondents' college teaching self-efficacy and TD experiences. To reduce this self-selection bias, we controlled for not only respondents' teaching experience, but also their career goals and interest in teaching at the start of doctoral studies, which are important factors affecting respondents' previous self-efficacy on college teaching. However, given the extent to which unobserved factors affect both TD participation and college-teaching self-efficacy, our estimates could be as biased as traditional regression models.
} 
9) participant's doctorate-granting institution, 10) level of interest in becoming a faculty member, 11), whether the participant completed his or her doctorate, and 12) whether TD participation was required.

According to social cognitive theory, one's self-efficacy beliefs are shaped by four sources of information: mastery experiences, vicarious experiences, verbal persuasion from others, and one's own emotional and physiological states (Bandura, 1997; Usher and Pajares, 2008). Of these four sources, mastery experiences are the most influential in shaping self-efficacy, "because [mastery experiences] provide the most authentic evidence of whether one can muster whatever it takes to succeed" (Bandura, 1997, p. 80). We therefore hypothesized that doctoral students would be exposed to the sources of self-efficacy information through not only participating in TD but also authentic teaching experiences (e.g., being a teaching assistant, guest lecturer, or instructor of record). Furthermore, we assumed that doctoral students with teaching experience were also likely to participate in TD programs. Thus, to test a relationship between the TD programs and college teaching selfefficacy, it was necessary to partial out the effect of teaching experience. Because the relationship between college teaching self-efficacy and the amount of college teaching experience was not linear, we included two continuous variables to take into account a nonlinear (quadratic) relationship between the amount of college teaching experience and each self-efficacy factor: 1) the cumulative amount of college teaching experience based on total semesters of diverse teaching activities (range $=0-22$ semesters; mean $=4.5$ semesters; $S D=4.1$ semesters); and 2) the rate of change of cumulative semesters with respect to each self-efficacy factor as a square term of cumulative semesters of college teaching experience. ${ }^{8}$

According to SCCT (Lent et al., 1994), students' initial career interests are likely to affect their participation in certain types of activities that may enhance their knowledge or skills in a given domain (e.g., TD programs, departmental training for teaching assistants). To adjust for their initial career aspirations, we controlled for three covariates: primary career goal, the level of interest in becoming a faculty member, and the level of interest in teaching when starting the doctoral program. Because SCCT views personal development as a recursive process - that is, one's performance leads back to new learning experiences-we assumed that, along with previous teaching experience, students' prior career goals and interests could be a proxy for baseline (prior) self-efficacy beliefs that we did not measure directly.

Although we followed a panel of late-stage doctoral students since 2009 , there could be significant variation in time to complete their doctorate. To account for possible cohort effects, we controlled for the year that doctoral study began and current academic status (i.e., whether students completed their doctorates). Because academic fields have structural differences

\footnotetext{
${ }^{8}$ This square term reflects a quadratic function of the amount of college teaching experience on each self-efficacy measure. The negative coefficients indicate that the effect of teaching experience decreases as the amount of teaching experience increases; see also Supplemental Figure 2. In addition, we examined the linear and cubic functions. Based on model fit statistics (e.g., likelihood ratio tests), a quadratic function was chosen to explain the relationship between the amount of college teaching experience and each self-efficacy measure. Test statistics will be provided upon request.
}

(Braxton and Hargens, 1996; Becher and Trowler, 2001), we accounted for differences among fields by including a series of dummy variables indicating respondents' principal fields of study. Finally, in some departments, participation in TD programs was required during doctoral training, which could be a source of self-selection bias in estimating the effect of the TD program. Thus, we also controlled for whether respondents' departments required TD participation (see Appendix A in the Supplemental Material for definitions of covariates and their descriptive statistics).

\section{ANALYSIS}

We estimated ordinary least-squares (OLS) regression of STEM doctoral students' college teaching self-efficacy beliefs on TD program participation, the degree of engagement in $\mathrm{TD}$, the type of TD, and the interaction of the TD experience with gender and race/ethnicity. To address our three research questions, we examined the relationship between TD experience and college teaching self-efficacy after accounting for appropriate covariates. To examine whether the effect of TD differed by gender or across race/ethnicity, we tested the interaction effects of race/ethnicity and gender with the TD program by adding the interaction terms of the TD experience with gender and race/ ethnicity. The effects of overall participation, engagement, and type of TD were estimated separately. Although SCCT supposes an indirect causal relationship between TD activities and college teaching self-efficacy beliefs, our observational research design does not permit strong inferences regarding causation.

\section{RESULTS}

As expected, we found that bivariate relationships of participation in TD with all six dimensions of college teaching selfefficacy_course planning, teaching methods, creating learning environment, assessing student learning, interacting with students, and mastering subject knowledge-were statistically significant $(p<0.05)$ and positive (see Supplemental Table 1$)$. Even after controlling for relevant covariates, we found that TD participants were more confident than nonparticipants in course planning and teaching methods.

\section{Degree of Engagement in TD}

While it was useful to know whether participation in TD on average is associated with gains in dimensions of college teaching self-efficacy, using a binary variable to represent TD participation has its limits. A continuous variable of TD engagement hours was used to examine linear relationships with each college teaching self-efficacy dimension. Table 1 shows results from the OLS regression of college teaching self-efficacy on degree of TD engagement. We found that greater engagement in TD was linearly associated with greater self-efficacy in every dimension except mastering subject knowledge, even after accounting for relevant covariates.

Figure 1 illustrates predicted score gains (standardized scores) in each college teaching self-efficacy factor as the degree of TD engagement increases. Spending approximately 50 hours on TD activities during doctoral training is associated with $0.16 \mathrm{SD}$ increase in confidence on course planning and teaching methods (0.032, $p<0.001$ in M1, and 0.033, $p<0.001$ in M2, Table 1; also see M1 and M2 in Figure 1). Although the effect is relatively small (0.021, $p<0.001$ in M4, Table 1), STEM early-career 
TABLE 1. OLS regression of college teaching self-efficacy on TD program engagement ${ }^{a}$

\begin{tabular}{|c|c|c|c|c|c|c|}
\hline Variable & $\begin{array}{c}\text { Course planning } \\
(\mathrm{b} / \mathrm{se})^{\mathrm{b}} \\
\mathrm{M}^{\mathrm{c}} \\
\end{array}$ & $\begin{array}{c}\text { Teaching } \\
\text { methods } \\
\text { (b/se) } \\
\text { M2 }\end{array}$ & $\begin{array}{c}\text { Creating learning } \\
\text { environment } \\
\text { (b/se) } \\
\text { M3 }\end{array}$ & $\begin{array}{c}\text { Assessing } \\
\text { student learning } \\
\text { (b/se) } \\
\text { M4 }\end{array}$ & $\begin{array}{c}\text { Interacting } \\
\text { with students } \\
\text { (b/se) } \\
\text { M5 } \\
\end{array}$ & $\begin{array}{c}\text { Mastering subject } \\
\text { knowledge } \\
\text { (b/se) } \\
\text { M6 } \\
\end{array}$ \\
\hline \multicolumn{7}{|l|}{ TD engagement (10 hours) } \\
\hline & $\begin{array}{l}0.032^{* * *} \\
(0.005)\end{array}$ & $\begin{array}{l}0.033^{* * *} \\
(0.005)\end{array}$ & $\begin{array}{c}0.013 * \\
(0.006)\end{array}$ & $\begin{array}{l}0.021 * * * \\
(0.006)\end{array}$ & $\begin{array}{c}0.013 * \\
(0.006)\end{array}$ & $\begin{array}{c}0.010 \\
(0.006)\end{array}$ \\
\hline \multicolumn{7}{|c|}{ Amount of teaching experience } \\
\hline Semester & $\begin{array}{l}0.110 * * * \\
(0.018)\end{array}$ & $\begin{array}{l}0.116^{* * * *} \\
(0.019)\end{array}$ & $\begin{array}{l}0.113^{* * *} \\
(0.020)\end{array}$ & $\begin{array}{l}0.113 * * * \\
(0.019)\end{array}$ & $\begin{array}{l}0.077^{* * *} \\
(0.020)\end{array}$ & $\begin{array}{l}0.056 * * \\
(0.020)\end{array}$ \\
\hline Semester squared & $\begin{array}{l}-0.004 * * * \\
(0.001)\end{array}$ & $\begin{array}{l}-0.004^{* * * *} \\
(0.001)\end{array}$ & $\begin{array}{l}-0.004 * * * \\
(0.001)\end{array}$ & $\begin{array}{l}-0.004 * * * \\
(0.001)\end{array}$ & $\begin{array}{c}-0.002 * \\
(0.001)\end{array}$ & $\begin{array}{c}-0.002 \\
(0.001)\end{array}$ \\
\hline Women (reference: men) & $\begin{array}{l}-0.259 * * * \\
(0.052)\end{array}$ & $\begin{array}{c}-0.119 * \\
(0.053)\end{array}$ & $\begin{array}{c}0.008 \\
(0.056)\end{array}$ & $\begin{array}{c}-0.120 * \\
(0.054)\end{array}$ & $\begin{array}{l}-0.227 * * * \\
(0.057)\end{array}$ & $\begin{array}{l}-0.235 * * * \\
(0.057)\end{array}$ \\
\hline \multicolumn{7}{|c|}{ Race/ethnicity (reference: underrepresented minority) } \\
\hline White & $\begin{array}{c}-0.216^{*} \\
(0.098)\end{array}$ & $\begin{array}{c}-0.174 \\
(0.100)\end{array}$ & $\begin{array}{l}-0.303 * * \\
(0.105)\end{array}$ & $\begin{array}{c}-0.072 \\
(0.103)\end{array}$ & $\begin{array}{c}-0.215^{*} \\
(0.107)\end{array}$ & $\begin{array}{c}-0.171 \\
(0.107)\end{array}$ \\
\hline Asian & $\begin{array}{c}-0.108 \\
(0.113) \\
\end{array}$ & $\begin{array}{c}-0.075 \\
(0.116) \\
\end{array}$ & $\begin{array}{c}-0.295^{*} \\
(0.122) \\
\end{array}$ & $\begin{array}{c}-0.013 \\
(0.119) \\
\end{array}$ & $\begin{array}{c}-0.169 \\
(0.124) \\
\end{array}$ & $\begin{array}{c}-0.273 * \\
(0.124) \\
\end{array}$ \\
\hline$N$ & 1261 & 1262 & 1260 & 1253 & 1253 & 1243 \\
\hline Adjusted $R^{2}$ & 0.241 & 0.201 & 0.105 & 0.158 & 0.110 & 0.095 \\
\hline \multicolumn{7}{|c|}{ 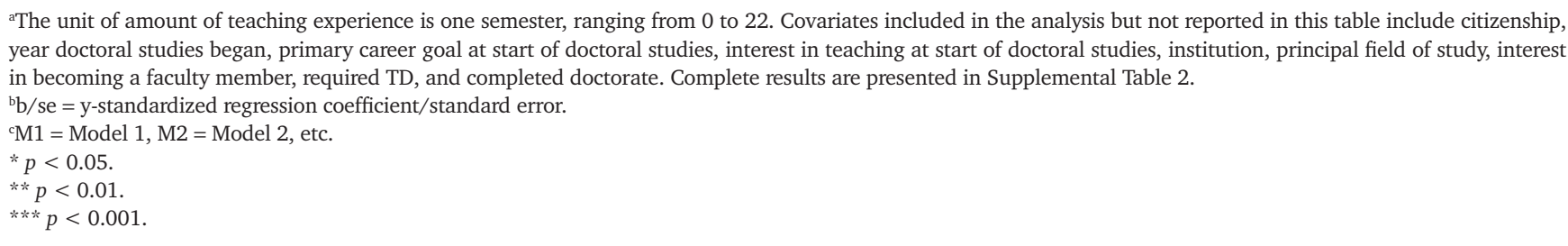 } \\
\hline
\end{tabular}

scholars still became significantly more confident in assessing student learning as they spent more time on TD activities. Care should be taken, however, when interpreting significantly positive associations of TD engagement with creating learning environment and interacting with students $(0.013, p<0.05$ in $\mathrm{M} 3$, and $0.013, p<0.05$ in M5, Table 1). As Figure 1 shows, the low slopes and largely overlapping 95\% confidence intervals in creating learning environment and interacting with students (see M3 and M5 in Figure 1) reflect very small effect sizes, calling into question their practical significance, even though they are statistically significant. Our supplemental analyses also revealed that only some respondents with extensive TD experience had significantly higher scores in creating learning environment and interacting with students than nonparticipants (i.e., TD engagement $=0)$. Thus, conservatively, we suggest that effects on these two dimensions are at best marginal and that further research is required to assess the robustness of these findings.

\section{Type of TD Program}

Table 2 shows results from the OLS regression of college teaching self-efficacy on the type of TD program (nonintensive, intensive, and formal courses). Participants in formal courses were significantly more confident than nonparticipants in course planning $(0.317, p<0.001$ in M1) and teaching methods (0.367, $p<0.001$ in M2). Participants in formal courses were even more confident in course planning than those in intensive TD programs (not reported, $p<0.05$ ). These findings suggest that participation in formal courses contributes to improving self-efficacy in two key dimensions of college teaching for STEM early-career scholars in a way that participation in only nonintensive TD courses does not.

It is worth noting that the type of TD program and the degree of engagement are correlated. That is, because formal courses and intensive TD activities require a substantial time commitment, their participants are likely to spend more time in TD programs than do participants in nonintensive TD activities. To partial out this relationship, we estimated the effect of TD engagement and the effect of TD type simultaneously (Table 2B). Even after accounting for the type of TD activities and relevant covariates, higher engagement was still significantly associated with greater confidence in five of six dimensions of college teaching; this is similar to results in Table 1, although their coefficients were slightly reduced. The significant effects of TD type on course planning and teaching methods in Table 2A were mostly explained by the inclusion of TD engagement in Table 2B. This finding suggests that the effects of TD type are mostly mediated by TD engagement. However, TD engagement may independently contribute to improving STEM early-career scholars' college teaching self-efficacy regardless of TD type.

Other covariates had an influence on college teaching selfefficacy. Table 1 clearly shows that teaching experience played an important role in improving STEM early-career scholars' college teaching self-efficacy. Even when other covariates were accounted for, STEM early-career scholars with more teaching 
(M1) Course Planning

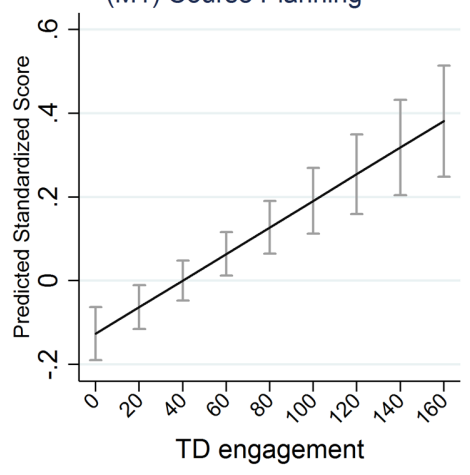

(M4) Assessing Student Learning

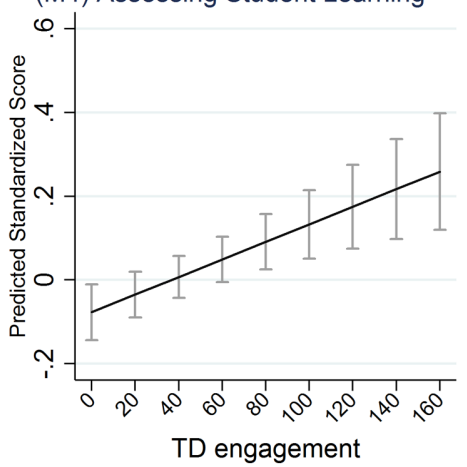

(M2) Teaching Methods

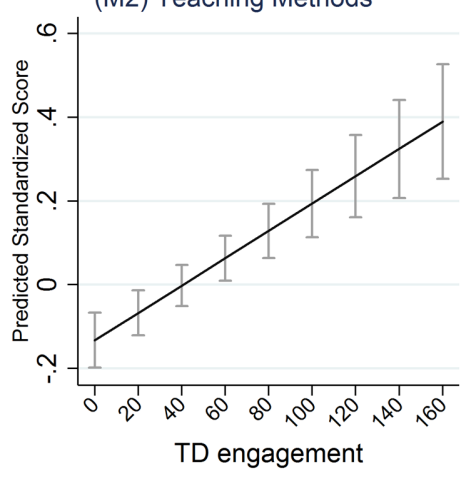

(M5) Interacting with Students

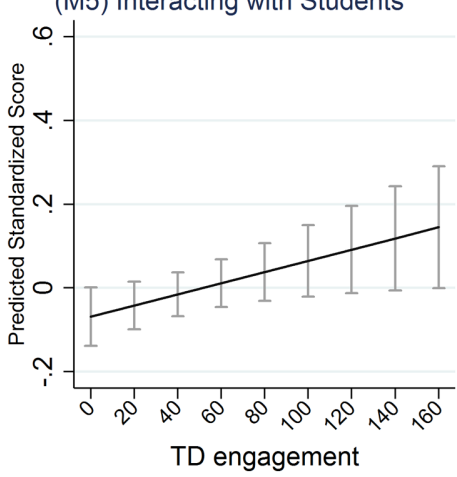

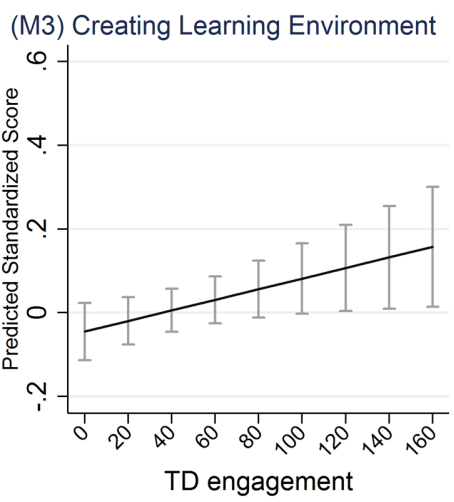

(M6) Mastering Subject Knowledge

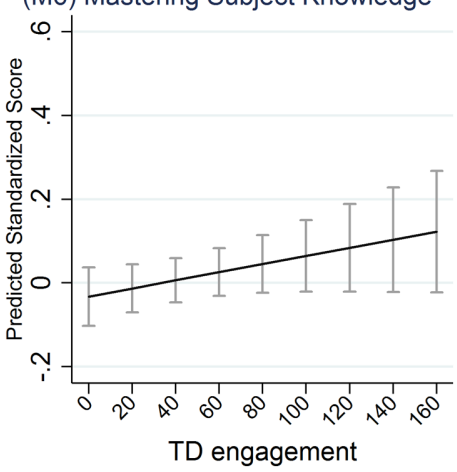

FIGURE 1. Predictive margins of each college teaching self-efficacy factor with $95 \% \mathrm{Cl}$ for the level of TD engagement. Predicted scores were estimated from each analytic model presented in Table 1 (Supplemental Table 2). Each $x$-axis unit represents 1 hour.

experience showed a higher level of confidence in all six dimensions of college teaching than those with less teaching experience. For example, four to five semesters of teaching experience during doctoral training correspond to approximately half of the SD increase in college teaching self-efficacy on course planning compared with those with no teaching experience (see M1 in Table 1 and Supplemental Figure 2). These findings indicate not only that actual teaching experience is positively associated with improving all dimensions of STEM early-career scholars' college teaching self-efficacy, but also that teaching experience and TD activities each has its own contribution.

\section{Interaction with Gender and Race/Ethnicity}

Table 3 shows interaction results from the OLS regression of self-efficacy on TD engagement and type (only main effects and interaction effects are presented; complete results are found in Supplemental Tables 5-7). In Table 3A, we include the degree of TD engagement and its interaction terms with gender and race/ethnicity. We found no significant interaction effect of race/ethnicity with any degree of TD engagement (not reported in Table 3). ${ }^{9}$ However, there were consistently positive interaction effects of TD engagement with gender on self-efficacy, especially for women's confidence in course planning and teaching methods. Figure 2 shows different rates of gains in confidence on course planning and teaching methods for

\footnotetext{
${ }^{9}$ Lack of interaction could be a result of a lack of power due to the very small sample size of participants from underrepresented minority groups.
}

early-career scholar men and women as they spent more time on TD activities during their doctoral programs. While women without TD experience were significantly less confident in course planning and teaching methods than men without TD experience, these gaps became significantly smaller as women became more engaged in TD activities. Women's confidence in course planning and teaching methods was not significantly different from that of men when women spent approximately more than 60-70 hours and 30 hours, respectively, on TD activities during their doctoral programs. ${ }^{10}$

Although Table 2 shows that participation in nonintensive TD activities, on average, had little relation to STEM earlycareer scholars' college teaching self-efficacy, Table 3B indicates that this is not the case for women. Women participants in nonintensive TD activities had stronger self-efficacy beliefs than women nonparticipants in course planning $(0.400, p<0.05$ in M1) and interacting with students $(0.515, p<0.05$ in M5), even after accounting for TD engagement. Even though there is no significant difference among different types of TD activities, this finding suggests that participating even in nonintensive TD

\footnotetext{
${ }^{10}$ In addition to confidence in course planning and teaching methods, interaction effects of being a woman with TD participation were statistically significant and positive in predicting confidence in assessing student learning and interacting with students ( $p<0.05$; see Supplemental Table 5). That is, on average, TD participation was more positively associated with women's confidence in four dimensions than men's. However, the rates of increase in confidence in assessing student learning and interacting with students corresponding to the degree of TD engagement were not significantly different between men and women.
} 
TABLE 2. OLS regression of college teaching self-efficacy on TD program type

\begin{tabular}{|c|c|c|c|c|c|c|}
\hline Variable & $\begin{array}{c}\text { Course planning } \\
(\mathrm{b} / \mathrm{se})^{\mathrm{b}} \\
\mathrm{M1}^{\mathrm{c}}\end{array}$ & $\begin{array}{l}\text { Teaching } \\
\text { methods } \\
\text { (b/se) } \\
\text { M2 } \\
\end{array}$ & $\begin{array}{c}\text { Creating learning } \\
\text { environment } \\
\text { (b/se) } \\
\text { M3 }\end{array}$ & $\begin{array}{c}\text { Assessing } \\
\text { student learning } \\
\text { (b/se) } \\
\text { M4 }\end{array}$ & $\begin{array}{c}\text { Interacting } \\
\text { with students } \\
\text { (b/se) } \\
\text { M5 }\end{array}$ & $\begin{array}{c}\text { Mastering subject } \\
\text { knowledge } \\
\text { (b/se) } \\
\text { M6 }\end{array}$ \\
\hline \multicolumn{7}{|l|}{ A. TD type only } \\
\hline \multicolumn{7}{|c|}{ TD type (reference: nonparticipants) ${ }^{\mathrm{d}}$} \\
\hline Nonintensive & $\begin{array}{c}0.048 \\
(0.086)\end{array}$ & $\begin{array}{c}0.068 \\
(0.088)\end{array}$ & $\begin{array}{c}0.062 \\
(0.092)\end{array}$ & $\begin{array}{c}0.094 \\
(0.089)\end{array}$ & $\begin{array}{c}0.057 \\
(0.093)\end{array}$ & $\begin{array}{c}0.144 \\
(0.094)\end{array}$ \\
\hline Intensive & $\begin{array}{c}0.116 \\
(0.098)\end{array}$ & $\begin{array}{c}0.248 \\
(0.101)\end{array}$ & $\begin{array}{c}0.125 \\
(0.105)\end{array}$ & $\begin{array}{c}0.116 \\
(0.102)\end{array}$ & $\begin{array}{c}-0.006 \\
(0.107)\end{array}$ & $\begin{array}{c}0.189 \\
(0.107)\end{array}$ \\
\hline Formal course & $\begin{array}{l}0.317^{* * *} \\
(0.085)\end{array}$ & $\begin{array}{l}0.367^{* \cdots *} \\
(0.088)\end{array}$ & $\begin{array}{c}0.099 \\
(0.092) \\
\end{array}$ & $\begin{array}{c}0.182 \\
(0.089) \\
\end{array}$ & $\begin{array}{c}0.078 \\
(0.093) \\
\end{array}$ & $\begin{array}{c}0.151 \\
(0.094) \\
\end{array}$ \\
\hline$N$ & 1261 & 1262 & 1260 & 1253 & 1253 & 1243 \\
\hline Adjusted $R^{2}$ & 0.241 & 0.201 & 0.105 & 0.158 & 0.110 & 0.095 \\
\hline \multicolumn{7}{|c|}{ B. TD type and engagement } \\
\hline Low ( $<10$ hours) & $\begin{array}{l}0.027^{* * * *} \\
(0.007)\end{array}$ & $\begin{array}{l}0.026^{* * * *} \\
(0.007)\end{array}$ & $\begin{array}{c}0.016 * \\
(0.007)\end{array}$ & $\begin{array}{l}0.024 * * * \\
(0.007)\end{array}$ & $\begin{array}{c}0.018 * \\
(0.007)\end{array}$ & $\begin{array}{c}0.010 \\
(0.007)\end{array}$ \\
\hline \multicolumn{7}{|c|}{ TD type (reference: nonparticipant) ${ }^{\mathrm{d}}$} \\
\hline Nonintensive & $\begin{array}{c}-0.010 \\
(0.087)\end{array}$ & $\begin{array}{c}0.014 \\
(0.089)\end{array}$ & $\begin{array}{c}0.032 \\
(0.094)\end{array}$ & $\begin{array}{c}0.049 \\
(0.091)\end{array}$ & $\begin{array}{c}0.024 \\
(0.095)\end{array}$ & $\begin{array}{c}0.132 \\
(0.095)\end{array}$ \\
\hline Intensive & $\begin{array}{c}0.012 \\
(0.101)\end{array}$ & $\begin{array}{c}0.149 \\
(0.104)\end{array}$ & $\begin{array}{c}0.075 \\
(0.110)\end{array}$ & $\begin{array}{c}0.031 \\
(0.106)\end{array}$ & $\begin{array}{c}-0.070 \\
(0.111)\end{array}$ & $\begin{array}{c}0.162 \\
(0.112)\end{array}$ \\
\hline Formal course & $\begin{array}{c}0.077 \\
(0.103) \\
\end{array}$ & $\begin{array}{c}0.139 \\
(0.106) \\
\end{array}$ & $\begin{array}{c}-0.031 \\
(0.111) \\
\end{array}$ & $\begin{array}{c}-0.026 \\
(0.107) \\
\end{array}$ & $\begin{array}{c}-0.074 \\
(0.112) \\
\end{array}$ & $\begin{array}{c}0.073 \\
(0.113) \\
\end{array}$ \\
\hline$N$ & 1273 & 1274 & 1272 & 1265 & 1265 & 1256 \\
\hline Adjusted $R^{2}$ & 0.234 & 0.197 & 0.103 & 0.152 & 0.109 & 0.093 \\
\hline \multicolumn{7}{|c|}{$\begin{array}{l}\text { aCovariates included in the analysis but not reported in this table include citizenship, year doctoral studies bega } \\
\text { in teaching at start of doctoral studies, institution, principal field of study, interest in becoming a faculty meml } \\
\text { bb/se = y-standardized regression coefficient/standard error. } \\
{ }^{\mathrm{c}} \mathrm{M} 1=\text { Model } 1, \mathrm{M} 2=\text { Model } 2 \text {, etc. } \\
\text { dBonferroni corrected } p \text { values were applied. Complete results are presented in Supplemental Tables } 3 \text { and } 4 . \\
{ }^{*} p<0.05 .\end{array}$} \\
\hline
\end{tabular}

activities could benefit women early-career scholars' college teaching self-efficacy beliefs, especially in course planning and interacting with students.

\section{DISCUSSION}

At a time of increasing concern over the preparation of future STEM faculty for their role as college teachers, ours is the first study to use SCCT to study the effects of doctoral TD on earlycareer scholars' teaching self-efficacy, which research shows is a strong predictor of successful teaching performance (Pajares, 1996; Sitzmann and Ely, 2011; Ross, 2013). The study examined whether early-career scholars' college teaching self-efficacy is associated with 1) any sort of participation in TD, 2) the degree of engagement in TD, and 3) the type of TD. Because self-efficacy sometimes varies by gender (Huang, 2013) and race/ethnicity (Lent et al., 2005; Byars-Winston et al., 2010), we also examined whether those characteristics interact with the effects of TD on college teaching self-efficacy.

Using regression analyses that accounted for key covariates, we found a significant connection between early-career scholars' participation in TD during their doctoral training and their college teaching self-efficacy beliefs, especially those related to their performance in course planning and teaching methods. Additionally, stronger self-efficacy beliefs about assessing student learning and interacting with students were significantly associated with not only higher TD engagement but also women's participation in TD activities.

\section{Relationship between TD Participation and College Teaching Self-Efficacy}

The key driver of human agency, asserts Bandura (1997), is one's beliefs about what one can accomplish. More so than knowledge, skill, and prior accomplishments, self-efficacy is a strong predictor of the degree of accomplishment that individuals eventually attain (Pajares, 1996; Sitzmann and Ely, 2011). Because teaching self-efficacy beliefs start to form during one's earliest teaching experiences and become more set over time (Woolfolk Hoy, 2004), it is important to help aspiring postsecondary faculty develop a strong sense of teaching self-efficacy during their doctoral training.

It is noteworthy, then, that our study found that participation in doctoral TD programs is closely linked with stronger 
TABLE 3. OLS Regression of college teaching self-efficacy on the interaction of women with TD program engagement and type ${ }^{a}$

\begin{tabular}{|c|c|c|c|c|c|c|}
\hline Variable & $\begin{array}{l}\text { Course } \\
\text { planning } \\
\text { (b/se) }^{\mathrm{b}} \\
\text { M1 }^{\mathrm{c}}\end{array}$ & $\begin{array}{l}\text { Teaching } \\
\text { methods } \\
\text { (b/se) } \\
\text { M2 }\end{array}$ & $\begin{array}{c}\text { Creating learning } \\
\text { environment } \\
\text { (b/se) } \\
\text { M3 }\end{array}$ & $\begin{array}{l}\text { Assessing student } \\
\text { learning } \\
\text { (b/se) } \\
\text { M4 }\end{array}$ & $\begin{array}{l}\text { Interacting } \\
\text { with students } \\
\text { (b/se) } \\
\text { M5 }\end{array}$ & $\begin{array}{c}\text { Mastering subject } \\
\text { knowledge } \\
\text { (b/se) } \\
\text { M6 }\end{array}$ \\
\hline \multicolumn{7}{|c|}{ A. Interaction of women with TD engagement } \\
\hline Women (reference: men) & $\begin{array}{l}-0.374 * * * * \\
(0.066)\end{array}$ & $\begin{array}{l}-0.235^{* * *} \\
(0.068)\end{array}$ & $\begin{array}{l}-0.054 \\
(0.071)\end{array}$ & $\begin{array}{l}-0.199 * * \\
(0.069)\end{array}$ & $\begin{array}{l}-0.253 * * * \\
(0.072)\end{array}$ & $\begin{array}{l}-0.295^{* * * *} \\
(0.073)\end{array}$ \\
\hline TD engagement (10 hours) & $\begin{array}{c}0.001 \\
(0.020)\end{array}$ & $\begin{array}{c}0.020 \\
(0.021)\end{array}$ & $\begin{array}{c}0.009 \\
(0.022)\end{array}$ & $\begin{array}{c}0.007 \\
(0.021)\end{array}$ & $\begin{array}{l}-0.004 \\
(0.022)\end{array}$ & $\begin{array}{l}-0.000 \\
(0.022)\end{array}$ \\
\hline $\begin{array}{l}\text { Interaction of women with TD } \\
\text { engagement }\end{array}$ & $\begin{array}{l}0.029 * * \\
(0.010)\end{array}$ & $0.029 * *$ & $(0.011)$ & $(0.011)$ & $(0.011)$ & $\begin{array}{c}0.017 \\
(0.011)\end{array}$ \\
\hline$N$ & 1261 & 1262 & 1260 & 1253 & 1253 & 1243 \\
\hline Adjusted $R^{2}$ & 0.244 & 0.204 & 0.108 & 0.158 & 0.112 & 0.096 \\
\hline \multicolumn{7}{|c|}{ B. Interaction of women with TD type } \\
\hline Women (reference: men) & $\begin{array}{l}-0.571 * * * \\
(0.117)\end{array}$ & $\begin{array}{l}-0.377 * * \\
(0.120)\end{array}$ & $\begin{array}{l}-0.112 \\
(0.126)\end{array}$ & $\begin{array}{l}-0.338 * * \\
(0.122)\end{array}$ & $\begin{array}{l}-0.512 * * * \\
(0.127)\end{array}$ & $\begin{array}{l}-0.371 * * \\
(0.129)\end{array}$ \\
\hline \multicolumn{7}{|c|}{ TD Type (reference: nonparticipants) ${ }^{\mathrm{d}}$} \\
\hline Nonintensive & $\begin{array}{c}-0.515 \\
(0.273)\end{array}$ & $\begin{array}{c}-0.490 \\
(0.281)\end{array}$ & $\begin{array}{l}-0.127 \\
(0.296)\end{array}$ & $\begin{array}{l}-0.398 \\
(0.287)\end{array}$ & $\begin{array}{l}-0.500 \\
(0.299)\end{array}$ & $\begin{array}{l}-0.183 \\
(0.301)\end{array}$ \\
\hline Intensive & $\begin{array}{c}0.070 \\
(0.317)\end{array}$ & $\begin{array}{c}0.245 \\
(0.327)\end{array}$ & $\begin{array}{c}0.293 \\
(0.344)\end{array}$ & $\begin{array}{l}-0.094 \\
(0.337)\end{array}$ & $\begin{array}{l}-0.291 \\
(0.351)\end{array}$ & $\begin{array}{c}0.016 \\
(0.353)\end{array}$ \\
\hline Formal course & $\begin{array}{l}-0.407 \\
(0.288)\end{array}$ & $\begin{array}{l}-0.110 \\
(0.297)\end{array}$ & $\begin{array}{l}-0.129 \\
(0.312)\end{array}$ & $\begin{array}{c}-0.414 \\
(0.302)\end{array}$ & $\begin{array}{c}-0.487 \\
(0.315)\end{array}$ & $\begin{array}{c}-0.308 \\
(0.316)\end{array}$ \\
\hline \multicolumn{7}{|l|}{ Interaction $^{\mathrm{d}}$} \\
\hline Women $\times$ nonintensive & $\begin{array}{l}0.400 * * \\
(0.148)\end{array}$ & $\begin{array}{c}0.318 \\
(0.152)\end{array}$ & $\begin{array}{c}0.147 \\
(0.160)\end{array}$ & $\begin{array}{c}0.283 \\
(0.155)\end{array}$ & $\begin{array}{l}0.515^{* *} \\
(0.162)\end{array}$ & $\begin{array}{c}0.232 \\
(0.164)\end{array}$ \\
\hline Women $\times$ intensive & $\begin{array}{c}0.169 \\
(0.164)\end{array}$ & $\begin{array}{c}0.159 \\
(0.169)\end{array}$ & $\begin{array}{c}0.005 \\
(0.178)\end{array}$ & $\begin{array}{c}0.243 \\
(0.172)\end{array}$ & $\begin{array}{c}0.269 \\
(0.180)\end{array}$ & $\begin{array}{c}-0.096 \\
(0.181)\end{array}$ \\
\hline Women $\times$ formal course & $\begin{array}{l}0.463^{* *} \\
(0.145)\end{array}$ & $\begin{array}{c}0.353 \\
(0.149)\end{array}$ & $\begin{array}{c}0.225 \\
(0.157)\end{array}$ & $\begin{array}{c}0.273 \\
(0.152)\end{array}$ & $\begin{array}{c}0.293 \\
(0.158)\end{array}$ & $\begin{array}{c}0.250 \\
(0.159)\end{array}$ \\
\hline$N$ & 1260 & 1261 & 1259 & 1252 & 1252 & 1243 \\
\hline Adjusted $R^{2}$ & 0.246 & 0.204 & 0.102 & 0.155 & 0.113 & 0.094 \\
\hline \multicolumn{7}{|c|}{$\begin{array}{l}\text { aOnly main and interaction effects are presented. Interaction effects of TD participation with race are not } \\
\text { included in the analysis but not reported in this table include citizenship, year doctoral studies began, pr } \\
\text { at start of doctoral studies, institution, principal field of study, interest in becoming a faculty member, } \mathrm{r} \\
\mathrm{b} \text { b/se = y-standardized regression coefficient/standard error. } \\
{ }^{\mathrm{c}} \mathrm{M} 1=\text { Model } 1, \mathrm{M} 2=\text { Model } 2 \text {, etc. } \\
{ }^{\mathrm{d} B o n f e r r o n i} \text { corrected } p \text { values were applied. Complete results are presented in Supplemental Table } 6 \text {. } \\
{ }^{* *} p<0.01 \text {. } \\
{ }^{* * * *} p<0.001 .\end{array}$} \\
\hline
\end{tabular}

college teaching self-efficacy across multiple dimensions of college teaching. TD participants were more confident than nonparticipants in their ability to handle various teaching activities, even after controlling for appropriate covariates such as gender, amount of teaching experience, and interest in becoming a faculty member. These findings are similar to those of Prieto and Meyers (1999), who found that formal training in teaching for 176 psychology graduate teaching assistants increased their sense of self-efficacy for college teaching.

As for why TD is associated with a greater sense of college teaching self-efficacy, our survey data did not directly address this question. From the perspective of SCCT, we postulate that
TD activities provide doctoral students with access to the four key sources of self-efficacy information (Bandura, 1997). For example, a course such as Teaching in the STEM College Classroom might afford doctoral students the opportunity to present a "teachable unit" (mastery experience), receive positive feedback from peers and instructors (verbal persuasion), observe how classmates carried out their own teachable units (vicarious experience), and experience certain levels of anxiety as they present (emotional or physiological arousal). Determining whether and how TD programs influence these sources of efficacy information, however, warrants further study. 

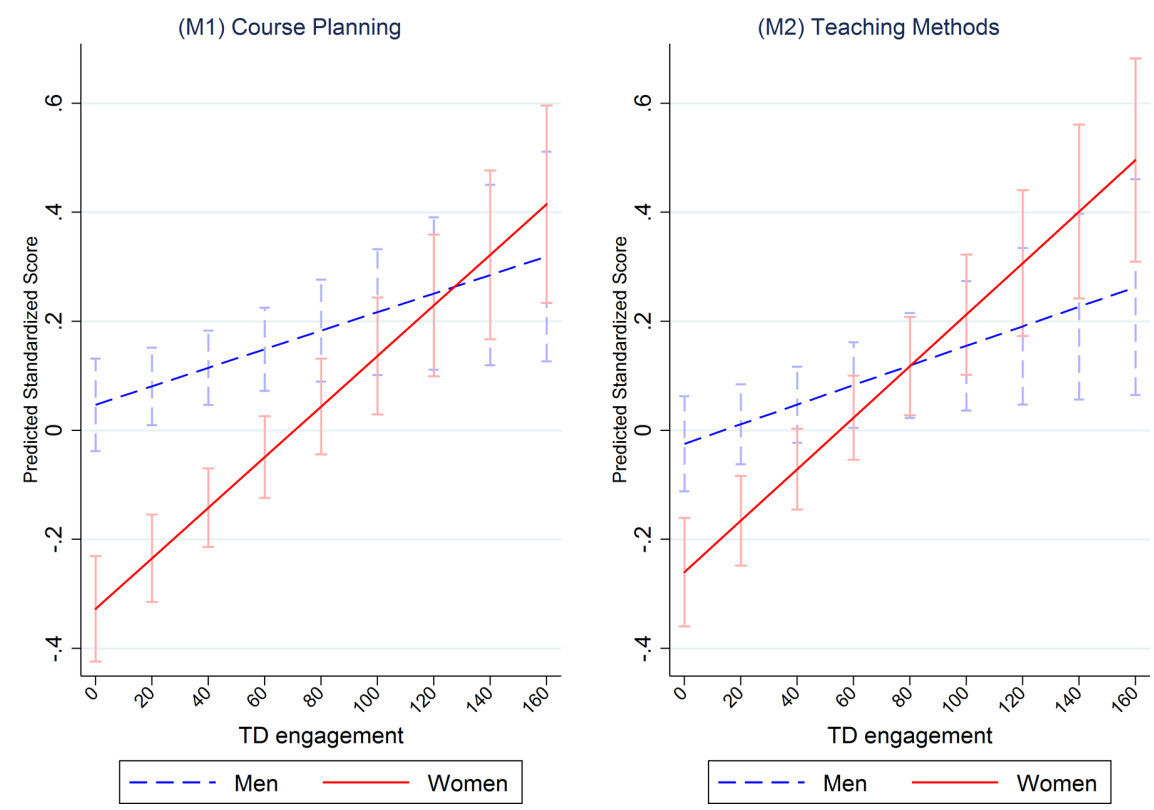

FIGURE 2. Predictive margins of each college teaching self-efficacy factor with $95 \% \mathrm{Cl}$ for the level of TD engagement by gender. Predicted scores were estimated from each analytic model presented in Table 3A (Supplemental Table 6). Each $x$-axis unit represents 1 hour.

\section{Relationship between the Degree of Engagement in TD and College Teaching Self-Efficacy}

Although we found that TD is valuable for participants on average, the amount of TD also matters. In her review of impact studies of $\mathrm{K}-12$ teacher professional development, Desimone (2009) argued that "there is a research consensus on the main features of professional development that have been associated with changes in knowledge, practice, and, to a lesser extent, student achievement" (p. 183). Of the five critical features Desimone identified, one was duration, which refers not only to the number of hours spent in professional development but also the span of time over which the activity is spread. For our study, we focused on the number of hours that participants reported to have spent in TD—what we call "degree of engagement."

In examining early-career scholars' degree of engagement in TD, we found that greater engagement was associated with greater gains in most dimensions of college teaching selfefficacy. As TD engagement increased (after accounting for covariates), participants were more confident in teaching methods, course planning, and assessment of student learning. That TD programs may be focused on these three areas is not a surprise. Extensive study has found that three evidencebased approaches have the greatest impact on undergraduate student learning and achievement: engaging, student-centered instructional strategies; assessments requiring higher-order cognitive skills (as opposed to lower-level skills such as recollection or categorization); and course design that aligns learning objectives, assessment activities, and in-class instruction, sometimes referred to as backward design (Wood, 2009; Momsen et al., 2010; Freeman et al., 2014; Wieman, 2014; Holt et al., 2015). Given the robust evidence supporting these three approaches, it is encouraging to find a result implying
TD programs have an appreciable effect on early-career instructors' confidence in these areas. Whether TD programs are intentionally focusing on these approaches, however, requires further study. Even though we found significant relationships of TD engagement with creating learning environment and interacting with students, we view these findings as exploratory and suggestive of potential effects, which may be further examined in the future by larger studies, because their estimates were somewhat sensitive across a range of engagement.

These findings about how TD engagement affects self-efficacy beliefs suggest that, in the effort to improve undergraduate STEM education, TD programs could contribute to instructional and curricular reform by promoting evidence-based approaches. When it comes to broadening the participation of women and underrepresented minorities in undergraduate STEM, however, TD may not yet be playing the role it could. This means TD providers might better explain to participants that effective undergraduate instruction includes not only knowing what to teach, how to teach, and how to assess whether students are learning, but also engaging all students in inclusive learning environments.

Finally, taking into account confidence intervals and effect sizes (see Figure 1), our findings suggest that low engagement in TD (e.g., fewer than 20-30 hours) has little effect on confidence in all six teaching dimensions. However, more than 30-40 hours of engagement in TD would lead to significant gains in college teaching self-efficacy, especially in course planning and teaching methods. Whether there is a threshold or a tipping point for TD effects on self-efficacy beliefs and other key outcomes must be studied further.

\section{Relationship between TD Type and College Teaching Self-Efficacy}

Drawing on previous research categorizing TD programs (Barger et al., 2010), we studied the outcomes of participation in three types of TD activities: nonintensive activities, intensive activities, and formal courses. Our findings suggest participation in formal courses significantly relates to STEM early-career scholars' college teaching self-efficacy beliefs in a way that intensive or nonintensive TD activities do not. One possible explanation is that formal courses provide more access to the four sources of self-efficacy information (Bandura, 1997; Usher and Pajares, 2008) than other types of TD do. However, because the effects of type are mostly explained by TD engagement, this finding suggests that the effects of formal courses are the result of exposure to sufficient TD time that provides more access to the four sources of self-efficacy information. That is, the impact of formal courses may lie in providing participants with enough time through repeated course meetings to access, interpret, and integrate the four sources of self-efficacy information. Because our measure of TD type did not attempt to distinguish among 
various types of TD courses, further research should focus on differences in formal courses' design and content.

\section{Interaction with Gender and Race/Ethnicity}

As noted, self-efficacy beliefs related to teaching and learning can vary by gender (Huang, 2013) and race/ethnicity (Lent et al., 2005; Byars-Winston et al., 2010). Although we found no interaction effects with race/ethnicity, the interaction effects with gender were generally significant for TD participation (four of six self-efficacy dimensions), higher TD engagement (two of six dimensions), and TD type. These positive interaction effects can be interpreted in two ways: women who participate in TD programs are more confident in STEM college teaching than either 1) women who do not participate or 2) men who participate in TD programs. The second interpretation, however, must be made with care, given that women are already significantly less confident in college teaching than men (see Table 1 and Figure 2) and that the main effects of being a woman are significantly negative and slightly bigger than the interaction effects (see Table 3). Thus, this positive interaction effect does not necessarily indicate that women participants are more confident in college teaching than men participants. Rather, it may suggest that TD participation nearly cancels out women participants' initial, comparatively lower college teaching self-efficacy beliefs (Figure 2). Moreover, although our findings suggest that participation in nonintensive TD activities is not associated with gains in college teaching self-efficacy in general, participation in nonintensive TD activities does benefit women's college teaching self-efficacy in course planning and interacting with students.

\section{The Relationship between Teaching Experience and College Teaching Self-Efficacy}

Although we intended to focus on the effects of TD on college teaching self-efficacy, our findings about the effects of actual teaching experience are worth mentioning. Our analyses show that teaching experience is significantly and uniquely associated with gains in college teaching self-efficacy beliefs. Thus, this finding suggests that combining TD with actual teaching experience could have the greatest effect on college teaching self-efficacy. This may be so because doctoral students and early-career scholars who combine the two not only enhance their teaching knowledge and skills but also gain crucial mastery experiences on which they can base ongoing judgments of their capability-perhaps leading to improved STEM college teaching performance in the future.

\section{Limitations}

This study is limited in several ways. First, while we collected information on doctoral students from three research universities, our institutional sample is not representative of the population of U.S. research universities (e.g., all three are public universities). Thus, care should be taken if attempting to generalize these results beyond the particular sample of institutions in this study. Second, we used self-report questionnaires to gather data. Although self-report data have the advantage of capturing people's feelings, behaviors, and experiences at relatively low cost, they have several potential problems regarding validity and reliability (Gonyea, 2005). Furthermore, doctoral students' responses to our retrospective questionnaires about their participation in TD and actual teaching experiences could be somewhat inaccurate, because recollection is never perfect. Better data would have come directly from TD programs' participation records, which we were not able to access. Third, although we had a high response rate for both the 2009 survey (73\%) and the 2011 survey $(67 \%)$, the 2011 respondents $(n=1445)$ were just $47 \%$ of the initial sample of 3060 . Although we found that attrition from the 2011 survey did not substantially change our results, our data may still suffer from nonresponse bias if those who did not respond to the 2009 survey were systematically different from those who did. Fourth, although our study used SCCT to examine self-efficacy beliefs, our data were not sufficient for examining SCCT's complex structural dynamics, in which self-efficacy plays a major role. Thus, rather than using structural equation modeling to examine structural relationships as a whole, this study used OLS regression to focus only on the relationship between students' experience in TD and college teaching self-efficacy. Finally, because this study is correlational in design, our regression estimates cannot be interpreted as showing causal effects. Additional research on potential causal relationships between TD program and college teaching self-efficacy is necessary, and this study provides evidence to further that inquiry.

\section{Implications for Practice, Policy, and Future Research}

Because each of the six STEM college teaching dimensions we measured were positively linked to either TD participation, engagement degree, or participation type, our study findings have important implications for the design and delivery of TD programs for doctoral students in STEM fields. One takeaway from this study concerns the amount of time that doctoral students might spend on TD activities. While it is useful to know that even a little TD has a statistically significant association with greater college teaching self-efficacy, our study suggests that more than 30-50 hours would be associated with practically meaningful gains in college teaching self-efficacy (Figure 1). Because prior research shows a strong relationship between teachers' sense of self-efficacy, actual teaching performance, and desired student outcomes (Pajares, 1996; Ross, 1998, 2013), increasing college teaching self-efficacy beliefs of future faculty may be a critical pathway to improving STEM undergraduate teaching and learning.

However, there are factors that complicate early-career scholars giving time to participate in TD. Skeptical advisors and peers may view doctoral students' time spent on TD as a waste of time or a way of avoiding one's research. In fact, participation in TD is sometimes stigmatized by faculty advisors in STEM fields, who may warn their advisees away from participation (Connolly et al., 2016). Another factor that may thwart doctoral student involvement in TD is that such activities at research-intensive universities are seldom offered to doctoral students in a coordinated manner. Various TD opportunities may be available within specific departments or colleges, or individual advisors may discuss teaching with their doctoral advisees on an ad hoc basis, but students often cannot count on a set of professional development opportunities being offered in a coordinated way. As a result, organizing one's TD experiences is typically a "do-it-yourself" experience. The time it takes to find these opportunities and assess the potential return on an 
investment in them is a real cost to doctoral students. Because their time is valuable and guarded by their advisors, their families, and themselves, helping doctoral students to find TD programs and assess their potential value would lower barriers to their participation in TD.

Notably, some graduate schools already organize TD opportunities into coherent frameworks, offering professional development at times convenient for doctoral students and effectively marketing what doctoral students-even those without faculty aspirations-may gain from participating. Michigan State University's PREP program is one example (Vergara et al., 2013). In addition, several nationally organized projects offer comprehensive programs to help doctoral students prepare for their teaching responsibilities. Two examples are the Center for the Integration of Research, Teaching, and Learning (Austin et al., 2008; Pfund et al., 2012) and the Council of Graduate Schools' program on Preparing Future Faculty to Assess Student Learning (Denecke et al., 2017). Programs that draw clear connections between the time spent in participation and the return on that investment are likely to gain greater buy-in from doctoral students, advisors, and administrators alike.

A second implication of this study stems from the finding that TD is especially helpful to women doctoral students. This is important because, in STEM fields, more women than men leave doctoral programs (Council of Graduate Schools, 2008), which has serious consequences for "sustaining our nation's scientific and technical prowess, building our domestic talent pool, and diversifying our professional, academic, and policy workforce" (Bernstein, 2011, p. 31). TD programs, as small-scale, proximal interventions (Bekki et al., 2013) may provide women doctoral students with not only greater pedagogical skill and understanding (Connolly and Lee, 2014) but also opportunities for the kinds of community that are key to their doctoral persistence. Moreover, women as early-career faculty typically face greater challenges than their male peers, including underrepresentation among tenure-track faculty, less time for research, and lower work-life satisfaction (Trautvetter, 1999; Trower and Bleak, 2004; Allan, 2011; Mason et al., 2013). Those who are better prepared for their teaching role by doctoral TD may experience less stress and more balance in carrying out their academic responsibilities (Benbow et al., 2011).

Third, although this study did not show that different types of TD are associated with different outcomes among all participants, our findings suggest that sufficient time in TD activities (i.e., formal courses) is associated with certain outcomes. Providing an institutional map of TD programs could not only help doctoral students find programs faster, but also help them find programs with TD outcomes they consider to be important to their professional development, such as course design or assessing student learning. Such a map of opportunities could be organized by key features of TD programs, such as duration, content, format, and selectivity (Barger et al., 2010; Connolly et al., 2010). In service to examining how different types of TD serve different outcomes, future research might explore the outcomes that do obtain from single or short-term TD opportunities (Zakrajsek, 2010).

Fourth, because combining TD with teaching experience may have a substantial impact on college teaching self-efficacy, STEM doctoral students should, time permitting, be encour- aged to participate in both types of activities during their doctoral training, and especially in those that purposefully integrate theory and practice. Exploring how to combine teaching experience and TD in ways that support the development of students' self-efficacy beliefs, teaching performance, and career formation would be a useful direction for future research.

Fifth, our findings suggest that SCCT could prove to be a useful framework for designing, studying, and evaluating TD programs. Drawing upon SCCT research, Hackett (2013) has asserted that educational and training interventions ought to purposefully cultivate self-efficacy, which in turn promotes academic- and career-related interests, choices, performance, and satisfaction. Hackett identified five characteristics of programs that intentionally foster self-efficacy: such programs 1) provide opportunities for participants to build competencies; 2) provide access to the four sources of self-efficacy information; 3) address participants' unrealistic expectations about the outcomes of learning experiences; 4) minimize contextual factors that inhibit self-efficacy and enhance those that facilitate it; and 5) help participants clarify academic and career goals. These characteristics could be applied to TD programs for STEM doctoral students by, for example, helping doctoral students clarify their career goals and the role they want teaching to play in their professional lives. Given the strong positive relationship between self-efficacy and eventual performance, we suggest that TD administrators consider using these characteristics to design, deliver, and evaluate their programs.

Finally, to fulfill the promise of TD as an important mechanism for improving undergraduate STEM education, experimental or quasi-experimental research is needed to understand whether doctoral TD directly affects self-efficacy beliefs and indirectly affects effective teaching performance. Additional longitudinal studies also are necessary because they not only allow researchers to test SCCT's causal hypotheses, but also can guide how SCCT is translated to practical applications (Lent et al., 2008).

\section{CONCLUSION}

Of the various ways to prepare doctoral students as future STEM scholars, TD programs have become more common at U.S. research universities. These programs are not commonplace, however, partly because we lack data about their impact on participants. Specifying the effects of TD programs may help them improve in specific ways and gain wider acceptance. It is important that key stakeholders know these three things about TD: a strong predictor of successful teaching performance is teaching self-efficacy; doctoral training, being a particularly influential stage in one's academic formation, is a crucial time to develop confidence in one's teaching abilities; and, as we found in this study, participation in doctoral TD is strongly associated with greater self-efficacy in certain dimensions of college teaching.

\section{ACKNOWLEDGMENTS}

We thank Shihmei Barger for contributions to the study, Bill Hoyt for statistical guidance, and Jenny Vandenberg and Sam Larson for assistance with preparing the article. These generous colleagues provided invaluable feedback on an early draft: Ann 
Austin, Janet Batzli, Bianca Bernstein, Laura Border, Rique Campa, Diane Ebert-May, Jim Fairweather, Joe Ferrare, Joanna Gilmore, Michelle Harris, Michelle Maher, Rick McGee, Hironao Okahana, Chris Pfund, Nancy Ruggeri, Beth Schussler, Amber Smith, Heather Thiry, and Xueli Wang. This material is based on work supported by the NSF under award 0817537. Any opinions, findings, and conclusions or recommendations expressed in this material are those of the authors and do not necessarily reflect the views of the NSF.

\section{REFERENCES}

Allan, E. J. (2011). Women's status in higher education: Equity matters. San Francisco, CA: Jossey-Bass.

Anderson, W. A., Banerjee, U., Drennan, C. L., Elgin, S. C. R., Epstein, I. R., Handelsman, J., ... Warner, I. M. (2011). Changing the culture of science education at research universities. Science, 331(6014), 152-153.

Association of American Universities. (2014). Framework for systemic change in undergraduate STEM teaching and learning. Retrieved January 31 2018, from www.aau.edu/sites/default/files/STEM\%20Scholarship/AAU _Framework.pdf

Austin, A. E. (2010). Reform efforts in STEM doctoral education: Strengthening preparation for scholarly careers. In Smart, J. C. (Ed.), Higher education: Handbook of theory and research (Vol. 25, pp. 91-128). Dordrecht, Netherlands: Springer.

Austin, A. E., Connolly, M. R., \& Colbeck, C. L. (2008). Strategies for preparing integrated faculty: The Center for the Integration of Research, Teaching, and Learning. In Colbeck, C. L., O'Meara, K., \& Austin, A. E. (Eds.), Educating integrated professionals: Theory and practice on preparation for the professoriate (New directions for teaching and learning 113) (pp. 69-81). San Francisco: Wiley.

Austin, A. E., \& McDaniels, M. (2006). Preparing the professoriate of the future: Graduate student socialization for faculty roles. In Smart, J. C. (Ed.), Higher education: Handbook of theory and research (Vol. 21, pp. 397456). New York: Springer.

Austin, A. E., \& Wulff, D. H. (2004). The challenge to prepare the next generation of faculty. In Wulff, D. H., \& Austin, A. E. (Eds.), Paths to the professoriate: Strategies for enriching the preparation of future faculty (pp. 316). San Francisco: Jossey-Bass.

Bandura, A. (1986). Social foundations of thought \& action: A social cognitive theory. Englewood Cliffs, NJ: Prentice Hall.

Bandura, A. (1997). Self-efficacy: The exercise of control, New York: Freeman.

Bandura, A. (2005). The evolution of social cognitive theory. In Smith, K. G., \& Hitt, M. A. (Eds.), Great minds in management (pp. 9-35). Oxford, UK: Oxford University Press.

Bandura, A. (2006). Guide for constructing self-efficacy scales. In Pajares, F. \& Urdan, T. (Eds.), Self-efficacy beliefs of adolescents (Vol. 5, pp. 307337). Greenwich, CT: Information Age.

Barger, S. S., Connolly, M. R., \& Savoy, J. N. (2010, April). A model of highly effective teaching-focused professional development programs. Paper presented at: the 90th Meeting of the American Educational Research Association (Denver, CO).

Baulch, B., \& Quisumbing, A. (2011). CPRC toolkit note: Testing and adjusting for attrition in household panel data. Retrieved January 31, 2018, from www.chronicpoverty.org/publications/details/testing-and-adjusting -for-attrition-in-household-panel-data

Beach, A. L., Sorcinelli, M. D., Austin, A. E., \& Rivard, J. K. (2016). Faculty development in the age of evidence: Current practices, future imperatives, Sterling, VA: Stylus.

Becher, T., \& Trowler, P. (2001). Academic tribes and territories: Intellectual enquiry and the cultures of discipline, Philadelphia, PA: Open University Press.

Bekki, J. M., Smith, M. L., Bernstein, B. L., \& Harrison, C. (2013). Effects of an online personal resilience training program for women in STEM doctoral programs. Journal of Women and Minorities in Science and Engineering, 19(1) $17-35$
Benbow, R. J., Byrd, D., \& Connolly, M. R. (2011). The Wisconsin longitudinal study of doctoral and postdoctoral teaching development: Key findings, Madison: Wisconsin Center for Education Research, University of Wisconsin-Madison

Bernstein, B. L. (2011). Managing barriers and building supports in science and engineering doctoral programs: Conceptual underpinnings for a new online training program for women. Journal of Women and Minorities in Science and Engineering, 17(1), 29-50.

Betz, N. E., \& Hackett, G. (2006). Career self-efficacy theory: Back to the future. Journal of Career Assessment, 14(1), 3-11.

Braxton, J. M., \& Hargens, L. L. (1996). Variation among academic disciplines: Analytical frameworks and research. In Smart, J. C. (Ed.), Higher education: Handbook of theory and practice (Vol. 11, pp. 1-46). New York: Agathon.

Byars-Winston, A., Estrada, Y., Howard, C., Davis, D., \& Zalapa, J. (2010). Influence of social cognitive and ethnic variables on academic goals of underrepresented students in science and engineering: A multiple-groups analysis. Journal of Counseling Psychology 57(2), 205-218.

Chism, N. V. N. (2007). Peer review of teaching: A sourcebook (2nd ed.). Bolton, MA: Anker.

Coalition for Reform of Undergraduate STEM Education. (2014). Achieving systemic change: A sourcebook for advancing and funding undergraduate STEM education. Retrieved January 31, 2018, from www.aacu.org/ sites/default/files/files/publications/E-PKALSourcebook.pdf

Connolly, M. R., \& Lee, Y.-G. (2014, April). The effects of doctoral teaching development programs on STEM doctoral students' college teaching competency. Paper presented at: the 94th Meeting of the American Educational Research Association (Philadelphia, PA).

Connolly, M. R., Savoy, J. N., \& Barger, S. S. (2010, May). Future-faculty professional development programs for doctoral students in science, technology, engineering, and mathematics: An exploratory classification scheme. Paper presented: at the meeting of the American Educational Research Association, Denver, CO.

Connolly, M. R., Savoy, J. N., Lee, Y.-G., \& Hill, L. B. (2016). Building a better future STEM faculty: How teaching development programs can improve undergraduate education. Madison: Wisconsin Center for Education Research, University of Wisconsin-Madison. Retrieved January 31, 2018 from http://lsfss.wceruw.org/finalreport/index.html

Council of Graduate Schools. (2008). Ph.D. completion and attrition: Analysis of baseline demographic data from the Ph.D. completion project. Washington, DC.

Cuddeback, G., Wilson, E., Orme, J. G., \& Combs-Orme, T. (2004). Detecting and statistically correcting sample selection bias. Journal of Social Service Research, 30(3), 19-33.

DeChenne, S. E., Enochs, L. G., \& Needham, M. (2012). Science, technology, engineering, and mathematics graduate teaching assistants teaching self-efficacy. Journal of the Scholarship of Teaching and Learning, 12(4), 102-123.

Denecke, D., Michaels, J., \& Stone, K. (2017). Strategies to prepare future faculty to assess student learning. Washington, DC: Council of Graduate Schools.

DeNeef, A. L. (2002). The Preparing Future Faculty program: What difference does it make? Washington, DC: Association of American Colleges and Universities.

Desimone, L. M. (2009). Improving impact studies of teachers' professional development: Toward better conceptualizations and measures. Educational Researcher, 38(3), 181-199.

Feldon, D. F., Peugh, J., Timmerman, B. E., Maher, M. A., Hurst, M., Strickland, D., ... Stiegelmeyer, C. (2011). Graduate students' teaching experiences improve their methodological research skills. Science, 333(6045), 10371039

Fitzgerald, J., Gottschalk, P., \& Moffitt, R. (1998). The impact of attrition in the Panel Study of Income Dynamics on intergenerational analysis. Journal of Human Resources, 33, 300-344.

Foster, E. M. \& Fang, G. Y. (2004). Alternative methods for handling attrition: An illustration using data from the fast track evaluation. Evaluation Review, 28(5), 434-464

Freeman, S., Eddy, S. L., McDonough, M., Smith, M. K., Okoroafor, N., Jordt, H., ... Wenderoth, M. P. (2014). Active learning increases student 
performance in science, engineering, and mathematics. Proceedings of the National Academy of Sciences USA, 111(23), 8410-8415.

Gaff, J. G., \& Lambert, L. M. (1996, July/August). Socializing future faculty to the values of undergraduate education. Change, 28, 38-45.

Golde, C. M., \& Dore, T. M. (2001). At cross purposes: What the experiences of today's doctoral students reveal about doctoral education. Philadelphia: Pew Charitable Trusts.

Goldsmith, S. S., Haviland, D., Dailey, K., \& Wiley, A. (2004). Preparing Future Faculty Initiative: Final evaluation report. Washington, DC: WestEd Evaluation Research Program and Abt Associates.

Gonyea, R. M. (2005). Self-reported data in institutional research. In Umbach, P. D. (Ed.), Survey research: Emerging issues (New directions for institutional research 127) (pp. 73-89). San Francisco: Jossey-Bass.

Hackett, G. (2013). Social cognitive career theory of career choice [PowerPoint slides]. Retrieved January 31, 2018, from www.umkc.edu/provost/ student-retention/documents/Social\%20Cognitive\%20Career\%20 Theory\%20February\%202013.ppt

Hativa, N. (2000). Teaching for effective learning in higher education. Norwell, MA: Kluwer Academic.

Henderson, C., Beach, A., \& Finkelstein, N. (2011). Facilitating change in undergraduate STEM instructional practices: An analytic review of the literature. Journal of Research in Science Teaching, 48(8), 952-984.

Hershock, C., Groscurth, C. R., \& Milkova, S. (2011). Approaches to preparing future faculty for teaching. In Cook, C. E., \& Kaplan, M. (Eds.), Advancing the culture of teaching on campus (pp. 97-117). Sterling, VA: Stylus.

Holt, E. A., Young, C., Keetch, J., Larsen, S., \& Mollner, B. (2015). The greatest learning return on your pedagogical investment: Alignment, assessment or in-class instruction? PLOS ONE, 10(9), e0137446.

Hopwood, N., \& Stocks, C. (2008). Teaching development for doctoral students: What can we learn from activity theory? International Journal for Academic Development, 13(3), 187-198.

Huang, C. J. (2013). Gender differences in academic self-efficacy: A meta-analysis. European Journal of Psychology of Education, 28(1), 135.

Huber, M. T. (2016). Foreword. In Condon, W., Iverson, E. R., Manduca, C. A., Rutz, C. \& Willett, G. (Eds.), Faculty development and student learning: Assessing the connections (pp. vi-xi). Bloomington: Indiana University Press.

Johnson, C. M., Ward, K. A., \& Gardner, S. K. (2017). Doctoral student socialization. In Shin, J. C., \& Teixeira, P. (Eds.), Encyclopedia of international higher education systems and institutions (pp. 1-4). Dordrecht, Netherlands: Springer.

Kalish, A., Robinson, S. S., Border, L., Chandler, E., Connolly, M. R., Eaton, L. J., ... von Hoene, L. (2011, Spring). Steps toward a framework for an intended curriculum for graduate and professional students: How we talk about what we do. Studies in Graduate and Professional Student Development, $14,163-173$

Klassen, R. M., \& Usher, E. L. (2010). Self-efficacy in educational settings: Recent research and emerging directions. In Urdan, T. C. \& Karabenick, S. A. (Eds.), The decade ahead: Theoretical perspectives on motivation and achievement (Vol. 16, pp. 1-33). Bingley, UK: Emerald.

Kober, N. (2015). Reaching students: What research says about effective instruction in undergraduate science and engineering. Washington, DC: National Academies Press.

Lee, V. S. (2010). Program types and prototypes. In Gillespie, K. H., \& Robertson, D. L. (Eds.), A guide to faculty development (2nd ed., pp. 21-33). San Francisco: Jossey-Bass.

Lent, R. W., \& Brown, S. D. (2006). On conceptualizing and assessing social cognitive constructs in career research: A measurement guide. Journal of Career Assessment, 14(1), 12-35.

Lent, R. W., Brown, S. D., \& Hackett, G. (1994). Toward a unifying social cognitive career theory of career and academic interest, choice, and performance. Journal of Vocational Behavior, 45(1), 79-122.

Lent, R. W., Brown, S. D., \& Hackett, G. (2000). Contextual supports and barriers to career choice: A social cognitive analysis. Journal of Counseling Psychology, 47(1), 36-49.

Lent, R. W., Brown, S. D., Sheu, H. B., Schmidt, J., Brenner, B. R., Gloster, C. S., ... Treistman, D. (2005). Social cognitive predictors of academic interests and goals in engineering: Utility for women and students at historically black universities. Journal of Counseling Psychology, 52(1), 84-92.

Lent, R. W., Lopez, A. M., Lopez, F. G., \& Sheu, H. B. (2008). Social cognitive career theory and the prediction of interests and choice goals in the computing disciplines. Journal of Vocational Behavior, 73(1), 52-62.

Lindley, L. D. (2006). The paradox of self-efficacy: Research with diverse populations. Journal of Career Assessment, 14(1), 143-160.

Lowman, J. (1995). Mastering the techniques of teaching (2nd ed.). San Francisco: Jossey-Bass.

Major, C. H., \& Dolly, J. P. (2003). The importance of graduate program experiences to faculty self-efficacy for academic tasks. Journal of Faculty Development, 19(2), 89-100.

Mason, M. A., Wolfinger, N. H., \& Goulden, M. (2013). Do babies matter? Gender and family in the ivory tower. New Brunswick, NJ: Rutgers University Press.

Miller, R. B., \& Hollist, C. S. (2007). Attrition bias. In Salkind, N. (Ed.), Encyclopedia of measurement and statistics (Vol. 1, pp. 57-60). Thousand Oaks, CA: Sage.

Momsen, J. L., Long, T. M., Wyse, S. A., \& Ebert-May, D. (2010). Just the facts? Introductory undergraduate biology courses focus on low-level cognitive skills. CBE-Life Sciences Education, 9(4), 435-440.

National Research Council (NRC) (2003). Evaluating and improving undergraduate teaching in science, technology, engineering, and mathematics. Washington, DC: National Academies Press.

NRC (2011). Rising above the gathering storm, revisited: Rapidly approaching category 5, Washington, DC: National Academies Press. Retrieved from https://doi.org/10.17226/13151

NRC (2012). Discipline-based education research: Understanding and improving learning in undergraduate science and engineering. Washington, DC: National Academies Press.

Office of Science and Technology Policy (2013). Federal science, technology, engineering, and mathematics (STEM) education: Five-year strategic plan. Retrieved January 31, 2018, from www.whitehouse.gov/sites/ whitehouse.gov/files/ostp/Federal_STEM_Strategic_Plan.pdf

Office of Science and Technology Policy. (2016). Progress report on coordinat ing federal science, technology, engineering, and mathematics (STEM) education. Retrieved January 31, 2018, from https://obamawhitehouse .archives.gov/sites/default/files/microsites/ostp/stem_budget _supplement_fy_17_final_0.pdf

Pajares, F. (1996). Self-efficacy beliefs in academic settings. Review of Educational Research, 66(4), 543-578.

Palmer, M. S. (2011, Spring). Graduate student professional development: A decade after calls for national reform. Studies in Graduate and Professional Student Development, 14, 1-17.

Patel, V. (2017). Training graduate students to be effective teachers; more colleges are making it a priority to teach future faculty members how to teach. Chronicle of Higher Education. Retrieved from January 31, 2018, www.chronicle.com/article/Training-Graduate-Students-to/240783

Pfund, C., Mathieu, R., Austin, A., Connolly, M. R., Manske, B., \& Moore, K. (2012, December 10). Advancing STEM undergraduate learning: Preparing the nation's future faculty. Change, 44, 64-72.

President's Council of Advisors on Science and Technology (2012). Engage to excel: Producing one million additional college graduates with degrees in science, technology, engineering, and mathematics. Washington, DC: U.S. Government Office of Science and Technology. Retrieved January 31, 2018, from www.whitehouse.gov/sites/default/files/microsites/ostp/pcast -engage-to-excel-final_feb.pdf

Prieto, L. R., \& Altmaier, E. M. (1994). The relationship of prior training and previous teaching experience to self-efficacy among graduate teaching assistants. Research in Higher Education, 35(4), 481-497.

Prieto, L. R., \& Meyers, S. A. (1999). Effects of training and supervision on the self-efficacy of psychology graduate teaching assistants. Teaching of Psychology, 26(4), 264-266.

Ross, J. A. (1998). The antecedents and consequences of teacher efficacy. In Brophy, J. (Ed.), Advances in research on teaching (Vol. 7, pp. 49-74). Greenwich, CT: JAI Press.

Ross, J. A. (2013). Teacher efficacy. In Hattie, J. \& Anderman, E. M. (Eds.), International guide to student achievement (pp. 266-267). New York: Routledge. 
Santiago, A. M., \& Einarson, M. K. (1998). Background characteristics as predictors of academic self-confidence and academic self-efficacy among graduate science and engineering students. Research in Higher Education, 39(2), 163-198.

Schönwetter, D. J., \& Ellis, D. (2010). Taking stock: Contemplating North American graduate student professional development programs and developers. In Miller, J. E., \& Groccia, J. E., (Eds.), To improve the academy (Vol. 29, pp. 3-17). San Francisco: Jossey-Bass.

Sitzmann, T., \& Ely, K. (2011). A meta-analysis of self-regulated learning in work-related training and educational attainment: What we know and where we need to go. Psychological Bulletin, 137(3), 421-442.

Suhr, D. (2006). Exploratory or confirmatory factor analysis (Paper 200-31) Cary, NC: SAS Institute.

Theall, M., Mullinix, B., \& Arreola, R. A. (2009). Promoting dialogue and action on meta-professional skills, roles, and responsibilities. In Nilson, L. B., \& Miller, J. E. (Eds.), To improve the academy (Vol. 28, pp. 115-138). San Francisco: Jossey-Bass.

Trautvetter, L. C. (1999). Experiences of women, experiences of men. In Menges, R. J. (Ed.), Faculty in new jobs: A guide to settling in, becoming established, and building institutional support (pp. 59-87). San Francisco: Jossey-Bass.

Trower, C. A., \& Bleak, J. L. (2004). Study of new scholars. Gender: Statistical Report [Universities]. Cambridge, MA: Harvard Graduate School of Education

Tschannen-Moran, M., \& Woolfolk Hoy, A. (2001). Teacher efficacy Capturing an elusive construct. Teaching and Teacher Education, 17(7) 783-805.

Usher, E. L., \& Pajares, F. (2008). Sources of self-efficacy in school: Critical review of the literature and future directions. Review of Educational Research, 78(4), 751-796.
Vergara, C. E., Urban-Lurain, M., Campa, H., Cheruvelil, K. S., Ebert-May, D. Fata-Hartley, C., ... Johnston, K. (2013). FAST-Future Academic Scholars in Teaching: A high-engagement development program for future STEM faculty. Innovative Higher Education, 39(2), 1-15.

Walker, G. E., Golde, C. M., Jones, L., Bueschel, A. C., \& Hutchings, P. (2008) The formation of scholars: Rethinking doctoral education for the twenty-first century. San Francisco: Jossey-Bass.

Weisbuch, R. (2004). Toward a responsive Ph.D.: New partnerships, paradigms, practices, and people. In Wulff, D. H., \& Austin, A. E. (Eds.), Paths to the professoriate: Strategies for enriching the preparation of future faculty (pp. 217-235). San Francisco: Jossey-Bass.

Wieman, C. E. (2014). Large-scale comparison of science teaching methods sends clear message. Proceedings of the National Academy of Sciences USA, 111(23), 8319-8320.

Wood, W. B. (2009). Innovations in teaching undergraduate biology and why we need them. Annual Review of Cell and Developmental Biology, 25 93-112.

Woolfolk Hoy, A. (2004). Self-efficacy in college teaching. Essays on teaching excellence: Toward the best in the academy (Vol. 15, pp 8-11). Fort Collins, CO: POD Network. Retrieved January 31, 2018, from https:// podnetwork.org/content/uploads/V15-N8-Woolfolk-Hoy.pdf

Wulff, D. H., \& Austin, A. E. (2004). Paths to the professoriate: Strategies for enriching the preparation of future faculty. San Francisco: Jossey-Bass.

Wurgler, E., VanHeuvelen, J. S., Rohrman, S., Loehr, A., \& Grace, M. K. (2013) The perceived benefits of a preparing future faculty program and its effect on job satisfaction, confidence, and competence. Teaching Sociology, 20, 1-11.

Zakrajsek, T. D. (2010). Important skills and knowledge. In Gillespie, K. H. Roberston, D. R., \& Associates (Eds.), A guide to faculty development (2nd ed., pp. 83-98). San Francisco: Jossey-Bass. 